medRxiv preprint doi: https://doi.org/10.1101/2021.06.24.21259079; this version posted June 25, 2021. The copyright holder for this preprint (which was not certified by peer review) is the author/funder, who has granted medRxiv a license to display the preprint in perpetuity. It is made available under a CC-BY-NC 4.0 International license.

\title{
Long term positivity of SARS-CoV-2 total immunoglobulins in convalescent plasma and blood donors
}

Running title: Evolution of SARS-CoV-2 antibodies

M Carmen Martín ${ }^{a}$

Ana Jimenez ${ }^{\mathrm{a}}$

Nuria Ortega

Alba Parrado

Isabel Page $\mathrm{e}^{\mathrm{a}}$

M Isabel González ${ }^{a}$

Lydia Blanco-Peris $^{a}$

${ }^{a}$ Centro de Hemoterapia y Hemodonación de Castilla y León

Keywords: total immunoglobulins, SARSCoV2, seroprevalence, blood donors

Corresponding author: M Carmen Martín; cmartinalo@saludcastillayleon.es; Centro de Hemoterapia y Hemodonación de Castilla y León, Paseo de Filipinos s/n, 47007 Valladolid, Spain

\section{Conflicts of interests}

MCM participates as lecturer in a sponsored symposium managed by Roche Diagnostics. No other conflicts have been identified.

\section{Sources of research support}

This work has been supported by Roche Diagnostics International Ltd., who provided free equipment and test reagents. Roche Diagnostics International Ltd. was not involved, either in study design, collection, analysis and interpretation of data, the writing of the report or in the decision to submit the article for publication. 
medRxiv preprint doi: https://doi.org/10.1101/2021.06.24.21259079; this version posted June 25, 2021. The copyright holder for this preprint (which was not certified by peer review) is the author/funder, who has granted medRxiv a license to display the preprint in perpetuity.

It is made available under a CC-BY-NC 4.0 International license.

\section{Acknowledgements}

LB and MCM conceived and designed the study. NO and AP acquired data, IP, AJ and MIG performed analysis and interpretation of laboratory data, MCM and LB drafted the article and revised it critically for important intellectual content, all authors provided final approval of the version to be submitted.

The authors thank to all blood donors for making this work possible by allowing research use of their samples by the Biobanco del Centro de Hemoterapia y Hemodonación de Castilla y León. They also thank the staff in charge of blood donation, and lab technicians for their efforts and from Roche Diagnostics International Ltd. for its support. 
medRxiv preprint doi: https://doi.org/10.1101/2021.06.24.21259079; this version posted June 25, 2021. The copyright holder for this preprint (which was not certified by peer review) is the author/funder, who has granted medRxiv a license to display the preprint in perpetuity.

It is made available under a CC-BY-NC 4.0 International license.

Long term positivity of SARS-CoV-2 total immunoglobulins in convalescent plasma and blood donors

Abstract

Background: One of the most questioned issues about SARS-CoV2 immunity is how long does it last. Whether lasting differences exist between infection and vaccination boosted immunity is yet to be known. The answer to this question will determine key issues such as the reliability of individual and herd immunity or the need of sanitary restrictions or periodical revaccination. The aim of this study was to determine how long total anti SARS-CoV2 antibodies due to past infection persist in peripheral blood and whether sex, age or haematological features can influence their lasting.

Material and Methods: A total of 2432 donations SARS-CoV-2 from 662 repeat donors from April 2020 to February 2021 were analysed. Donors were $69.7 \%$ males and their average age was 46. An automated chemilumiscence immunoassay for total antibodies recognizing N protein of SARS-CoV-2 in human serum and plasma was performed.

Results and discussion: In 97.6\% donors with follow-up, anti SARS-CoV-2 protein $\mathrm{N}$ total antibodies remained positive up to 46 weeks after first positive determination. Blood group was not related to antibody waning. Lower lymphocyte counts and higher neutrophils and as well higher seric $\lg A$ would help predict future negativization of antibodies. The vast majority of donors keep their total immunoglobulins anti SARS-CoV-2 positive for longer than 10 months. Ageing might have a protective effect against antibody waning but, given the small number of cases that become negative, more studies, or larger cohorts would be needed to confirm these facts.

Keywords: COVID-19, antibodies, immunity, immunoglobulins, SARS-CoV-2 
medRxiv preprint doi: https://doi.org/10.1101/2021.06.24.21259079; this version posted June 25, 2021. The copyright holder for this preprint (which was not certified by peer review) is the author/funder, who has granted medRxiv a license to display the preprint in perpetuity.

\section{Introduction}

One of the most questioned issues about SARS-CoV2 immunity is how long does

3 it last. Although evidence exists of SARS-COV-2 infection inducing long-lived bone marrow specific plasma cells even in mild cases [1], it's not yet established whether infection or vaccination boosted immunity will last as long. The answers to this question would determine key issues such as the reliability of individual 7 and herd immunity or the need of sanitary restrictions or periodical revaccination.

Most SARS-CoV-2 infected individuals develop an effective immune response, leading to viral eradication and the production of specific $T$ cell responses and antibodies against SARS-CoV-2 that are usually detectable 10-21 days after infection $[2,3]$.

Antibody assays are not equivalent: they either detect antibodies against different viral proteins ( $\mathrm{S} 1, \mathrm{~S} 1 / \mathrm{S} 2, \mathrm{RBD}$ or $\mathrm{NC}$ ) or different immunoglobulin classes: IgG, $\operatorname{lgM}, \lg A$ or their combinations. Many factors can influence test performance, including cross-reactivity with other coronaviruses, that can occur in up to $28 \%$ individuals [2] or platform (laboratory-based vs point-of-care, lateral flow). Chemiluminiscence assays have suitable performances regarding both sensibility and sensitivity and correlate with titres of neutralizing antibodies [4].

Antibody responses against viral $S$ and $N$ proteins are equally sensitive in the acute phase of infection, but antibody responses against $\mathrm{N}$ seem to wane in the post infection phase whereas those against the $\mathrm{S}$ protein would persist over time with a slow decay $[1,5]$

Even if antibody levels waned, long-lived mononuclear blood cells (MBCs) and long-lived bone marrow plasma cells would remain to mediate rapid antibody production triggered by a new contact with the virus. Some studies suggest that SARS-CoV-2 infection strengthens pre-existing broad coronavirus protection through S2-reactive antibody and MBCs formation [6]

Antibody evolution surveys are most useful to monitor the pandemic, both before and after vaccination strategies [7]. There are several features that should be taken into account, including time lapse between infection and antibody 
medRxiv preprint doi: https://doi.org/10.1101/2021.06.24.21259079; this version posted June 25, 2021. The copyright holder for this preprint (which was not certified by peer review) is the author/funder, who has granted medRxiv a license to display the preprint in perpetuity.

It is made available under a CC-BY-NC 4.0 International license .

31 development or antibody waning. Blood donors constitute a representative subset of population aged 18-65 and are reasonably free of biases that could over represent symptomatic or exposed individuals.

Heterogeneity of susceptibility and transmission is hard to evaluate but does exist [8]. A portion of the population may have pre-existing immunity via crossreactivity or particular host factors such as mucosal immunity or trained innate immunity protection (as it has been reported to be conferred by Diphtheriapertussis-tetanus (DPT) or Bacillus Calmette-Guérin (BCG) vaccination [9]. There is as well a proportion of post infection seronegative individuals that develop immunity by $\mathrm{T}$ cell mediated responses but without exhibiting an antibody response [10].

To date it is not possible to ascertain whether antibodies can last longer than the time COVID-19 has been among us. There are recently described early cases in France [10], arising the question of whether the pathogen could have been circulating even before the recording of the first cases in Spain by January $31^{\text {st }}$, 2020. Our fist positive donations are from 2019, possibly due to cross-reaction to previous coronaviruses [11] but we decided to start our series on January $13^{\text {th }}$, the donation date of our first positive after WHO issued a comprehensive package of technical guidance online with advice to all countries on how to detect, test and manage potential cases.

Our starting hypothesis was that the vast majority of either recovered or asymptomatic SARS-CoV-2 cases would develop and keep antibodies against the novel coronavirus [1, 2, 9]. They will subsequently contribute to herd immunity. Anyone holding antibodies due to prior infection, should be kept from receiving the second dose of vaccines requiring booster, so far their cellular response could even result impaired [12].

The main aim of this study was to determine which percentage of the seropositive population due to natural infection keeps total antibodies recognizing SARS-CoV2 and how long can they last. A secondary goal was to establish whether sex, age, blood group or haematological features might influence the fact of keeping or loosing circulating antibodies. This knowledge would help optimize immunization strategies, and would ease decisions about the need of 
medRxiv preprint doi: https://doi.org/10.1101/2021.06.24.21259079; this version posted June 25, 2021. The copyright holder for this preprint (which was not certified by peer review) is the author/funder, who has granted medRxiv a license to display the preprint in perpetuity.

It is made available under a CC-BY-NC 4.0 International license.

periodical revaccination either overall or for determined population groups by reliably knowing the lasting of specific humoral immunity.

\section{METHODS}

The aim of this study was to determine how long anti SARS-CoV2 antibodies persisted in peripheral blood, and whether haematological o demographical parameters would be related to it. A retrospective testing and information compilation was performed

Plasma-EDTA and serum frozen samples from blood, plasma (normal and convalescent) and platelet donations were tested. A total of 2432 aleatorized samples of 662 donors over 18 years old were included. Donation is allowed after one month after the end of COVID-19 symptoms in our country. The Biobank of the Centro de Hemoterapia de Castilla y León is included in the National Registry of Biobanks (RD17 / 16/2011) with the number B.0000264 and holds an ISO 9001: 2015 certification endorsing our granting of safety and traceability of any human biological sample we distribute, always behaving Spanish and European rules on human samples and data protection management.

All haematological and demographic data were extracted from electronic database eDelphyn (Hemasoft). Variables analyzed included age, sex, blood group, and laboratory data: leukocyte (WBC), neutrophil, lymphocyte, platelet,

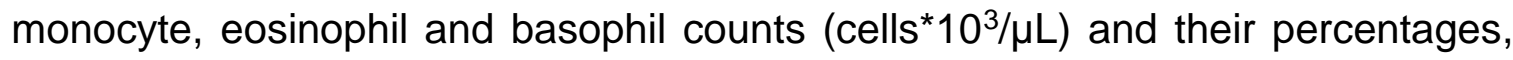
serum immunoglobulins $\lg \mathrm{G}$, $\lg A$ and $\lg M(\mathrm{mg} / \mathrm{dL})$, haemoglobin $(\mathrm{Hb})$ and haematocrit $(\mathrm{HCT})$.

An automated chemiluminiscence double-antigen sandwich immunoassay for the in vitro semi quantitative detection of total antibodies to SARS-CoV-2 in human serum and plasma was performed. The target antigen of this immunoassay is a recombinant nucleocapsid $(\mathrm{N})$ protein. Elecsys ${ }^{\circledR}$ Anti-SARS-CoV-2 (Roche Diagnostics, Basel, Switzerland) detects antibodies correlating with virusneutralizing ones and is therefore useful to help characterize the immune reaction to SARS-CoV-2 [9, 10]. Immunoassay was validated by our serology lab by testing of 6 pairs of samples (plasma EDTA and serum) from diagnosed PCRpositive, symptomatic cases infected by mid-April, that were previously reported positive by the Spanish National Microbiology Centre, and checked to be as well 
medRxiv preprint doi: https://doi.org/10.1101/2021.06.24.21259079; this version posted June 25, 2021. The copyright holder for this preprint (which was not certified by peer review) is the author/funder, who has granted medRxiv a license to display the preprint in perpetuity.

It is made available under a CC-BY-NC 4.0 International license .

95 positive for IgG (Chemiluminiscence, N protein, Abbott Alinity S, Chicago USA) and IgA (ELISA, S protein, Euroimmunn, Lübeck, Germany) antiSARS-CoV-2. Another set of ten prepandemic samples, therefore supposed to be negative, were equally analysed. 405 donations were analysed both in serum and plasma to verify interchangeability. A $100 \%$ concordance was yielded by all these validation assays. The cut-off was that recommended by manufacturer $(O D>1$ to report reactivity). Researchers performing anti SARS-CoV-2 analyses were blind to the condition of COVID-19 convalescence and to any other characteristic of the donors or to the donation dates.

Demographic and clinical characteristics of patients are expressed as their mean and standard deviation (SD) for continuous variables and frequency distributions are reported for categorical variables. Age was analysed both as continuous and categorical variable; in the latter case was recoded into 4 groups: under $30, \geq 30$ and $<45, \geq 45$ and $<60$, and, last, $\geq 60$ and $>75$ years old.

Donors whose second OD were under $90 \%$ of the first of that of their first positive were recoded into decay group. Donors over $110 \%$ were recoded as rise and those who were $+/-10 \%$ of the first one were in the stay group.

Kolmogorov-Smirnov test was performed on each continuous variable to contrast normality. None of the variables followed normal distributions, therefore nonparametric Mann Whithney $U$ test was performed to compare laboratory values. To contrast the Ho of independence within categorical variables, Pearson's Chisquare and Fisher's exact test were carried out. Any test was considered to be significant at a $95 \%$ confidence level.

This study was conducted according with national regulations, institutional policies and in the tenets of the Helsinki Declaration, it was approved by the Valladolid Health Area Drug Research Ethics Committee, in a meeting held on June 11th, 2020 with the reference number "BIO-2020-93". Included donors consented to participate in Biobank research activities. The privacy rights of human subjects were always observed.

\section{Results}

A total of 2432 donations (either whole blood, plasmapheresis or platelet apheresis) were tested for total anti SARS-CoV2 antibodies recognizing $\mathrm{N}$ 
medRxiv preprint doi: https://doi.org/10.1101/2021.06.24.21259079; this version posted June 25, 2021. The copyright holder for this preprint (which was not certified by peer review) is the author/funder, who has granted medRxiv a license to display the preprint in perpetuity.

It is made available under a CC-BY-NC 4.0 International license .

127 protein. Donors made up 662; 69.7\% males, aged 18-75, average 46+/-12, $12846.3 \%$ A, 43.1\% O, 6.5\% B, 4.1 \% AB. Donations were selected at random 129 among those collected from 13 $3^{\text {th }}$ January 2020 (date of the first 2020 positive 130 found) to $11^{\text {th }}$ February 2021.

131250 donors were positive at least once (provided a second donation after the 132 positive one was analyzed) and therefore their 340 donations selected for further 133 analysis. 62 donors had more than 2 positive donations. Average time gap 134 between samples was 12.31 weeks (1-46, $S D=10.01)$.

135

136

137

138

139

140

141

142

143

144

145

146

147

148

149

150

151

152

We considered the first positive sample of the donor within the assessed period as first donation of this study. Out of the 250 initially positive donors, only 6 (2.4\%) became negative at any moment of their follow-up (Figure 1 ).

$2 \%$

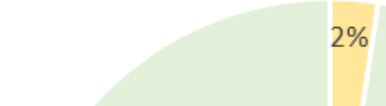

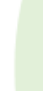

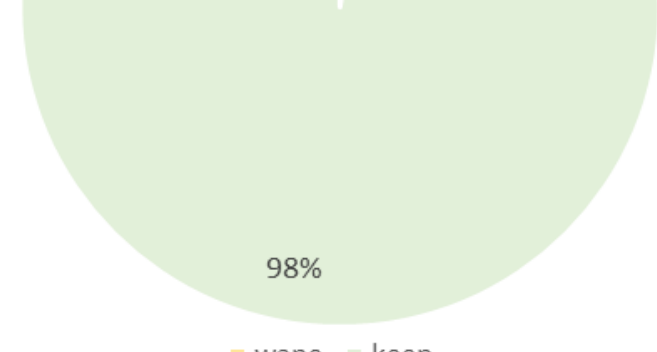

wane keep

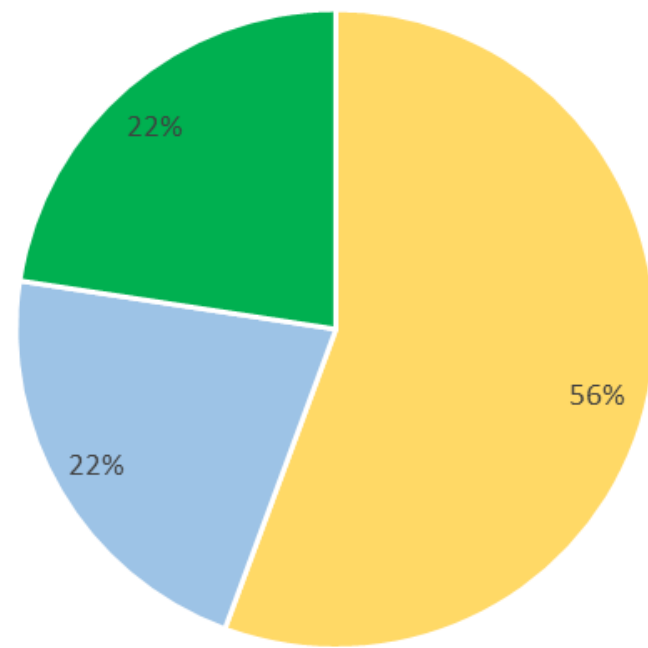

$0^{\prime}$

Iation

positive, second, negative; decay: OD of second donation under $90 \%$ of the first one; stay: OD of second donation $+/-10 \%$ of the first one; rise: OD of second donation over $110 \%$ of the first one)

Only 6 out of 250 donors lost their antibodies, all of them after just one positive donation. They were two males in their fifties and four women, two in their fifties again and two younger ones (Table1). No other wane events were found. All waning cases were weak positives $(O D<2.5)$ in their first positive donation. 
medRxiv preprint doi: https://doi.org/10.1101/2021.06.24.21259079; this version posted June 25, 2021. The copyright holder for this preprint (which was not certified by peer review) is the author/funder, who has granted medRxiv a license to display the preprint in perpetuity.

DO1 DO2 Weeks

\begin{tabular}{ccccccc} 
Sex & $\mathbf{n}$ & Age group & Blood group & $(\operatorname{mean}(\mathbf{S D}))$ & $(\boldsymbol{m e a n}(\mathbf{S D}))$ & $(\boldsymbol{m e a n}(\mathbf{S D}))$ \\
\hline Male & 2 & $\geq 45$ and $<60$ & $\mathrm{~A}, \mathrm{O}$ & $1.51(0.59)$ & $0.55(0.05)$ & $12(1.41)$ \\
Female & 1 & under 30 & $\mathrm{~A}$ & $1.05(-)$ & $0.88(-)$ & $26(-)$ \\
& 1 & $\geq 30$ and $<45$ & $\mathrm{~A}$ & $1.08(-)$ & $0.56(-)$ & $14(-)$ \\
& 2 & $\geq 45$ and $<60$ & $\mathrm{O}$ & $1.06(0.02)$ & $0.72(0.23)$ & $20(8.49)$ \\
\hline
\end{tabular}

155 Table 1. Characteristics of donors loosing anti SARS-CoV-2 antibodies, optical

156 density (OD) and interval between positive and negative donations (weeks) with 157 total immunoglobulin to SARS-CoV2 becoming negative (OD1: optical density of 158 first positive donation, OD2 optical density of consecutive donation to the first 159 positive one)

$16097.6 \%$ donors kept positive their total antibodies against SARS-CoV-2. The 161 longest period lapse between first and last donation was 46 weeks. No 162 relationship with age, blood group or sex was found. Neither was found as 163 comparing raw $O D$ values.

164 No relationship of waning or OD changes due to blood group (Table 2) was 165 found. Rising OD was less frequent within the under 30 group as a trend $166 \quad(\mathrm{OR}=0.4 ; \mathrm{Cl}(0.13-1.21) ; \mathrm{p}=0.149)$. Waning was more frequent in women as a 167 trend $(\mathrm{OR}=3.56 ; \mathrm{Cl}(0.64-19.8))$.

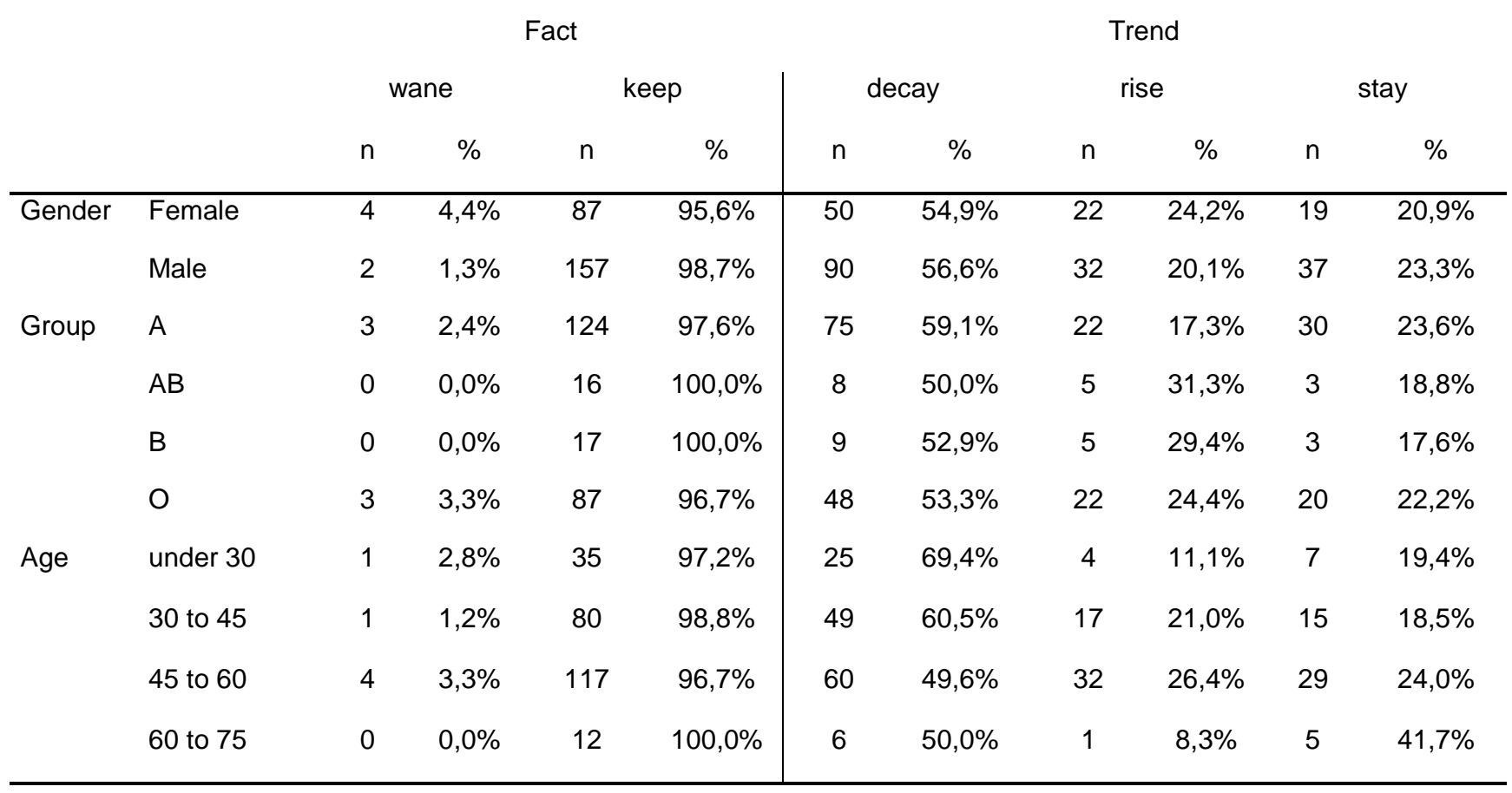


medRxiv preprint doi: https://doi.org/10.1101/2021.06.24.21259079; this version posted June 25, 2021. The copyright holder for this preprint (which was not certified by peer review) is the author/funder, who has granted medRxiv a license to display the preprint in perpetuity.

It is made available under a CC-BY-NC 4.0 International license .

168 169

170

171

172

173

174

175

176

177

178

179

180

181

182

183

184

185

186

Table 2. Donor changes in seropositivity and OD for anti SARS-CoV-2 total immunoglobulins by sex, blood group and age group.

Haemogram parameters (leukocytes, neutrophils, lymphocytes, monocytes, eosinophils, basophils, haematocrit and haemoglobin) from each donor were tested for its relationship with antibody waning (Table 2). Lymphocyte percent was significantly lower $(25.4 \%$ vs. $31.7 \%$; $=0.021)$ conversely to neutrophil percent (65.1 vs $59.1 ; p=0.024)$ in those donors whose antibodies would wane. $\lg \mathrm{A}$ was found to be higher as a trend (324 vs. $227 \mathrm{mg} / \mathrm{dL} ; \mathrm{p}=0.153$ ), as well as platelets (279.7 vs. $247.1 ; p=0.166)$ and neutrophil count (5.2 vs 4.2; $p=0.129)$ (Table 3).

When an age-stratified analysis was performed, some facts become noticeable as regarding just the $\geq 45$ and $<60$ group: higher leukocytes arose as a significant difference in those who would wane (9.65 vs. 6.59; $p=0.047$ ), The difference in platelets is more evident as regarding just this group (327 vs. 231 $\mathrm{p}=0.019$ ), the same happens with neutrophils both in absolute numbers (5.59 vs. 3.78; $p=0.019$ ) and percent (66.95 vs $58.25 ; p=0.014)$, lymphocyte count ( 1.86 vs 2.02; $p=0.005)$, monocyte number ( 0.58 vs $0.41 ; p=0.028)$. Eosinophils were lower under 45 : in under 30 group ( 0.02 vs $0.12 p=0.049)$ and in $\geq 45$ and $<60$ group (0.23 vs. $0.15 ; p=0.034$ ) (Supplementary Table 1 ).

\begin{tabular}{|c|c|c|c|c|c|}
\hline & $\begin{array}{l}\stackrel{\nu}{\frac{N}{N}} \\
\stackrel{0}{\lessgtr}\end{array}$ & 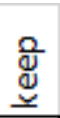 & $\begin{array}{l}\text { त् } \\
\text { d }\end{array}$ & 空 & $\stackrel{\Perp}{\frac{n}{L}}$ \\
\hline Age & $\Downarrow$ & - & $\downarrow$ & - & - \\
\hline IgA & $\uparrow$ & - & - & - & - \\
\hline Platelets & $\uparrow$ & - & - & - & - \\
\hline WBC & - & - & - & - & - \\
\hline Neutrophil count & $\uparrow$ & - & - & - & - \\
\hline Neutrophil \% & $\uparrow$ & - & - & - & - \\
\hline Lymphocyte count & - & - & - & $\downarrow$ & - \\
\hline Lymphocyte \% & $\Downarrow$ & - & - & - & - \\
\hline Basophil \% & - & - & - & $\uparrow$ & - \\
\hline
\end{tabular}

Figure 2. Significant changes in hematological parameters related to changes in anti SARS-CoV-2 total antibodies (wane: first donation positive, second, negative; decay: OD of second donation under $90 \%$ of the first one; stay: OD of second donation $+/-10 \%$ of the first one) 
medRxiv preprint doi: https://doi.org/10.1101/2021.06.24.21259079; this version posted June 25, 2021 . The copyright holder for this preprint (which was not certified by peer review) is the author/funder, who has granted medRxiv a license to display the preprint in perpetuity.

It is made available under a CC-BY-NC 4.0 International license.

\begin{tabular}{|c|c|c|c|c|c|c|}
\hline & & & $\mathrm{n}$ & mean & SD & IQR \\
\hline \multirow[t]{2}{*}{ Age } & & Wane & 6 & 43.8 & 9.6 & $34.7-50.1$ \\
\hline & $p=0.153$ & Keep & 331 & 45.0 & 10.8 & $37.6-54.1$ \\
\hline \multirow[t]{2}{*}{$\lg A$} & & Wane & 5 & 324.4 & 149.3 & $191-443$ \\
\hline & & Keep & 164 & 227.3 & 82.5 & $166-274$ \\
\hline \multirow[t]{2}{*}{$\lg G$} & & Wane & 5 & 1003.4 & 122.2 & $892-1092$ \\
\hline & & Keep & 164 & 1053.3 & 166.2 & $955.5-1153$ \\
\hline \multirow[t]{2}{*}{$\operatorname{lgM}$} & & Wane & 5 & 101.2 & 41.6 & $85-138$ \\
\hline & & Keep & 164 & 121.2 & 63.1 & $78-151.5$ \\
\hline \multirow[t]{2}{*}{ WBC count } & & Wane & 5 & 8.1 & 2.7 & $6.8-9.7$ \\
\hline & & Keep & 326 & 7.0 & 1.8 & $5.8-7.9$ \\
\hline \multirow[t]{2}{*}{ Platelets } & & Wane & 6 & 279.7 & 56.6 & $43.3-48.4$ \\
\hline & & Keep & 328 & 247.1 & 51.4 & $42.9-47.3$ \\
\hline \multirow[t]{2}{*}{ Haematocrit } & & Wane & 6 & 46.1 & 3.8 & $226-328$ \\
\hline & & Keep & 328 & 45.1 & 3.0 & $211.5-274.5$ \\
\hline \multirow[t]{2}{*}{ Neutrophil count } & & Wane & 6 & 5.2 & 1.9 & $43.3-48.4$ \\
\hline & $p=0.129$ & Keep & 328 & 4.2 & 1.5 & $42.9-47.3$ \\
\hline \multirow[t]{2}{*}{ Neutrophil \% } & $*$ & Wane & 6 & 65.1 & 4.9 & $226-328$ \\
\hline & $p=0.024$ & Keep & 328 & 59.1 & 7.8 & $211.5-274.5$ \\
\hline \multirow[t]{2}{*}{ Lymphocyte count } & & Wane & 6 & 1.9 & 0.4 & $4.4-6.7$ \\
\hline & & Keep & 328 & 2.2 & 0.6 & $3.2-4.8$ \\
\hline \multirow[t]{2}{*}{ Lymphocyte \% } & * & Wane & 6 & 25.4 & 6.1 & $64.7-68.9$ \\
\hline & $p=0.021$ & Keep & 328 & 31.7 & 7.0 & $54-63.9$ \\
\hline \multirow[t]{2}{*}{ Monocyte count } & & Wane & 6 & 0.5 & 0.2 & $1.7-2$ \\
\hline & & Keep & 328 & 0.4 & 0.1 & $1.8-2.5$ \\
\hline \multirow[t]{2}{*}{ Monocyte\% } & & Wane & 6 & 6.3 & 0.7 & $20.9-26.8$ \\
\hline & & Keep & 328 & 6.2 & 1.3 & $27.5-36.3$ \\
\hline \multirow[t]{2}{*}{ Eosinophil count } & & Wane & 6 & 0.2 & 0.2 & $0.4-0.7$ \\
\hline & & Keep & 328 & 0.2 & 0.1 & $0.3-0.5$ \\
\hline \multirow[t]{2}{*}{ Eosinophil \% } & & Wane & 6 & 2.9 & 2.7 & $5.8-6.7$ \\
\hline & & Keep & 328 & 2.4 & 1.7 & $5.3-7.1$ \\
\hline \multirow[t]{2}{*}{ Basophil count } & & Wane & 6 & 0.0 & 0.0 & $0.1-0.3$ \\
\hline & & Keep & 328 & 0.0 & 0.0 & $0.1-0.2$ \\
\hline \multirow[t]{2}{*}{ Basophil \% } & & Wane & 6 & 0.5 & 0.1 & $1.8-2.8$ \\
\hline & & Keep & 328 & 0.5 & 0.3 & $1.3-3.1$ \\
\hline
\end{tabular}

193 Table 3. Age and laboratory data in donations keeping or waning antibodies 194 Wane: present donation positive, next one, negative; keep: both positive 
medRxiv preprint doi: https://doi.org/10.1101/2021.06.24.21259079; this version posted June 25 , 2021. The copyright holder for this preprint (which was not certified by peer review) is the author/funder, who has granted medRxiv a license to display the preprint in perpetuity.

It is made available under a CC-BY-NC 4.0 International license .

195 ODs decayed as considering consecutive pairs of donations in 140 donors 196 (56.0\%, mean lapse between analysis, 9.5 weeks), rose in 54 (21.6\%, mean 197 lapse 11 weeks) cases and stayed $+/-10 \%$ in 56 (22.4\%, mean lapse 5.43 198 weeks) donors (Figure 1, Table 4). Donors whose ODs decayed were 199 significantly younger ( 43 vs $47 ; p=0.042$ ). The ones whose OD due to anti SARS200 CoV-2 total antibodies stayed $+/-10 \%$ had lower $\operatorname{lgA}$ as a trend $(191.5 \mathrm{mg} / \mathrm{dL}$ vs. 201224.3 or $227.5 \mathrm{mg} / \mathrm{dL} ; \mathrm{p}=0.048)$ and a higher percent of basophils $(0.6 \%$ vs. $2020.5 \% ; p=0.146)$

\begin{tabular}{|c|c|c|c|c|c|}
\hline & & $\mathrm{n}$ & mean & SD & IQR \\
\hline Age & decay & 202 & 43.7 & 45.0 & $10.8-36.2$ \\
\hline \multirow[t]{2}{*}{$* p=0,042$} & stay & 74 & 46.5 & 47.4 & $10.8-39.4$ \\
\hline & rise & 60 & 47.5 & 49.7 & $10.3-40.4$ \\
\hline $\lg A$ & decay & 101 & 243.2 & 227.0 & $92.5-167$ \\
\hline \multirow[t]{2}{*}{$*_{p}=0,048$} & stay & 35 & 197.6 & 184.0 & 69-151 \\
\hline & rise & 33 & 224.7 & 208.0 & $73.2-172$ \\
\hline \multirow[t]{3}{*}{$\lg G$} & decay & 101 & 1067.1 & 1071.0 & $165.8-973$ \\
\hline & stay & 35 & 1021.3 & 1012.0 & $176.3-836$ \\
\hline & rise & 33 & 1037.3 & 1061.0 & $148.6-940$ \\
\hline \multirow[t]{3}{*}{$\lg M$} & decay & 101 & 115.6 & 107.0 & 57.1-78 \\
\hline & stay & 35 & 130.7 & 109.0 & $72-87$ \\
\hline & rise & 33 & 125.1 & 112.0 & $68.1-74$ \\
\hline \multirow[t]{3}{*}{ WBC count } & decay & 198 & 7.1 & 6.8 & $1.8-5.8$ \\
\hline & stay & 74 & 6.8 & 6.7 & $1.7-5.7$ \\
\hline & rise & 58 & 6.9 & 6.6 & $1.7-5.7$ \\
\hline \multirow[t]{3}{*}{ Platelets } & decay & 200 & 249.9 & 236.0 & $53.9-212$ \\
\hline & stay & 74 & 242.3 & 242.0 & $45.2-213$ \\
\hline & rise & 59 & 245.7 & 234.0 & $51.2-204$ \\
\hline \multirow[t]{3}{*}{ Hematocrit } & decay & 200 & 45.2 & 45.2 & $3-43.2$ \\
\hline & stay & 74 & 44.8 & 45.3 & $2.9-42.6$ \\
\hline & rise & 59 & 45.3 & 44.5 & $3.3-42.8$ \\
\hline \multirow[t]{3}{*}{ Neutrophil count } & decay & 200 & 4.3 & 4.1 & $1.6-3.2$ \\
\hline & stay & 74 & 4.1 & 3.8 & $1.5-3.3$ \\
\hline & rise & 59 & 4.0 & 3.7 & $1.2-3.1$ \\
\hline \multirow[t]{3}{*}{ Neutrophil \% } & decay & 200 & 59.7 & 60.0 & $8-54.7$ \\
\hline & stay & 74 & 59.3 & 59.0 & $7.8-54$ \\
\hline & rise & 59 & 57.4 & 56.7 & $6.8-53$ \\
\hline \multirow[t]{3}{*}{ Lymphocyte count } & decay & 200 & 2.2 & 2.1 & $0.6-1.8$ \\
\hline & stay & 74 & 2.0 & 2.0 & $0.4-1.7$ \\
\hline & rise** & 59 & 2.3 & 2.1 & $0.7-1.8$ \\
\hline \multirow[t]{3}{*}{ Lymphocyte \% } & decay & 200 & 31.2 & 31.3 & 7.3-26.6 \\
\hline & stay & 74 & 31.2 & 31.2 & $6.8-26.4$ \\
\hline & rise** & 59 & 33.5 & 33.3 & $6.1-29.4$ \\
\hline
\end{tabular}


medRxiv preprint doi: https://doi.org/10.1101/2021.06.24.21259079; this version posted June 25, 2021. The copyright holder for this preprint (which was not certified by peer review) is the author/funder, who has granted medRxiv a license to display the preprint in perpetuity.

It is made available under a CC-BY-NC 4.0 International license.

$\begin{array}{llcccc}\text { Monocyte count } & \text { decay } & 200 & \mathbf{0 . 4} & 0.4 & 0.1-0.3 \\ & \text { stay } & 74 & \mathbf{0 . 4} & 0.4 & 0.1-0.4 \\ & \text { rise } & 59 & \mathbf{0 . 4} & 0.4 & 0.1-0.3 \\ \text { Monocyte \% } & \text { decay* } & 200 & \mathbf{6 . 2} & 6.0 & 1.3-5.3 \\ & \text { stay } & 74 & \mathbf{6 . 4} & 6.4 & 1.2-5.7 \\ & \text { rise } & 59 & \mathbf{6 . 2} & 6.3 & 1.2-5.2 \\ \text { Eosinophil count } & \text { decay } & 200 & \mathbf{0 . 2} & 0.1 & 0.1-0.1 \\ & \text { stay } & 74 & \mathbf{0 . 2} & 0.1 & 0.1-0.1 \\ & \text { rise } & 59 & \mathbf{0 . 2} & 0.1 & 0.1-0.1 \\ \text { Eosinophil \% } & \text { decay } & 200 & \mathbf{2 . 4} & 1.9 & 1.8-1.3 \\ & \text { stay } & 74 & \mathbf{2 . 5} & 2.0 & 1.7-1.3 \\ \text { Basophil count } & \text { rise } & 59 & \mathbf{2 . 4} & 2.1 & 1.5-1.3 \\ & \text { decay } & 200 & \mathbf{0 . 0} & 0.0 & 0-0 \\ & \text { stay } & 74 & \mathbf{0 . 0} & 0.0 & 0-0 \\ \text { Basophil \% } & \text { rise } & 59 & \mathbf{0 . 0} & 0.0 & 0-0 \\ \text { p=0,146 } & \text { decay } & 200 & \mathbf{0 . 5} & 0.5 & 0.3-0.4 \\ & \text { stay } & 74 & \mathbf{0 . 6} & 0.5 & 0.3-0.4 \\ & \text { rise } & 59 & \mathbf{0 . 5} & 0.5 & 0.2-0.4\end{array}$

Table 4. Age and laboratory donation data layered by OD observed changes in total anti SARS-CoV-2 antibodies (rise: the second determination was over 110\% of the first; stay: OD of the second donation was $90 \%-110 \%$ of the first one; decay: OD of the second donation was under $90 \%$ of the first one)

\section{Discussion}

There is little literature on SARS-CoV-2 antibody waning. Antibodies recognizing $\mathrm{N}$ protein of SARS-CoV-2 have been elsewhere reported to wane in the post infection phase while those against the $S$ protein would persist over time [13]. Additionally, the antibody response would be robust in patients with severe infection and weaker in those with mild infection or asymptomatic individuals. Although $71 \%$ of repeat donors in this study were convalescent plasma donors, one of our limitations is that we cannot recall how many of them developed severe symptoms. Some reports at the beginning of pandemics pointed out that up to $40 \%$ asymptomatic cases could lose their antibodies after 6 weeks from acute infection [13] but our data don't support that statement. More recent studies [1] demonstrate that durable serum antibodies would be granted by long-lived plasma cells. Our study confirms that most individuals would keep their antibodies for 10 months or longer. Our results agree as well to others reporting a high percentage of individuals (above $75 \%$ ) keeping antibodies positive for at least 9 months even when a titer decline is patent [14]. That would mean at least 
medRxiv preprint doi: https://doi.org/10.1101/2021.06.24.21259079; this version posted June 25, 2021. The copyright holder for this preprint (which was not certified by peer review) is the author/funder, who has granted medRxiv a license to display the preprint in perpetuity.

It is made available under a CC-BY-NC 4.0 International license .

22350 weeks after contagion so far they're not allowed to donate until 1 month after 224 resolution of symptoms.

225 Specific immunoglobulins would became detectable within 5-7 days post infection 226 and seroconversion would happen after 10-14 days. Detectable levels of 227 neutralizing antibodies against SARS-CoV-2 have been shown to start declining 228 within three months of infection, especially among mild and asymptomatic cases 229 [15]. Accordingly, one half (56.0\%, Figure 1) of our donors exhibit a decay in their 230 OD from total immunoglobulins anti SARS-COV-2 assay although most of them 231 remain positive.

232 Antibody waning would be independent of blood group in our cohort. Specific anti 233 SARS-CoV-2 immunoglobulin loss would be a rare event slightly more frequent in 234 women and a decay would be more frequent in younger donors. Mature age 235 would determine longer antibody half-life [14]. Ageing is one of the most important determinants in COVID-19 severity $[16,17]$ and it would have a role as well in humoral response keeping but larger cohorts and replication analyses should be performed to determine whether a an age-titer correlation exists because of the small rate of waning cases.

240 Lower lymphocyte and higher neutrophil percent might indicate future antibody 241 waning. High neutrophil/lymphocyte ratios are somehow related to impaired 242 immune responses with a high inflammatory component and cytokine storm [18]. 243 Our findings would reinforce the hypothesis of a not so robust response that 244 would weaken in the medium term. Some of these changes are more evident in 245 mid- aged cases, an ageing effect cannot be discarded but the low number of 246 waning cases, and the fact that none of them was older than 51 keeps us from 247 further ascertainments, even when it points out a very interesting topic for future 248 analyses.

249 Total, non-specific, high $\lg A$ together with higher platelet count and lower 250 neutrophil count might precede antibody waning as well. It is well known that 251 several infectious agents such as malaria have prothrombotic effects, which 252 happen as well in bacterial sepsis [19]. It has been elsewhere reported an 253 elevation of platelets and their activation and a lower number and activity of 
medRxiv preprint doi: https://doi.org/10.1101/2021.06.24.21259079; this version posted June 25, 2021. The copyright holder for this preprint (which was not certified by peer review) is the author/funder, who has granted medRxiv a license to display the preprint in perpetuity.

It is made available under a CC-BY-NC 4.0 International license.

254 neutrophils in COVID-19 cases irrespective of their severity [20] accordingly to 255 our data.

256 Secreted IgA is known to play a key role in SARS-CoV-2 immunity but very little 257 is known on circulating $\lg A$ [21]. $\lg G$ in combination with $\lg M$ and $\lg A$ would have 258 greater neutralization capacity than IgG alone, a broader repertoire of antibodies 259 correlates with a stronger SARS-CoV-2 neutralization [22]. Initial IgA 260 plasmablast's response declines quickly, whereas IgA-producing plasma cells 261 persist for years in mucosae [23]. It might explain that individuals mounting a 262 strong $\lg$ A response would seem to loose antibodies, but it will be interesting to 263 check out whether salivary IgA remains positive or not so far IgA antibodies are 264 the major component of the neutralizing antibodies developed in response to 265 SARS-CoV-2 infection [24]

266 Lower lymphocyte counts and higher neutrophils and as well higher seric $\lg A$ 267 would help predict future negativization of antibodies. The vast majority of donors 268 keep their total immunoglobulins anti SARS-CoV-2 positive for longer than 10 269 months. Ageing might have a protective effect against antibody waning but, given 270 the small number of cases that become negative, more studies, or larger cohorts 271 would be needed to confirm these facts. 
medRxiv preprint doi: https://doi.org/10.1101/2021.06.24.21259079; this version posted June 25, 2021. The copyright holder for this preprint

\section{Bibliography}

1. Turner JS, Kim W, Kalaidina E, Goss CW, Rauseo AM, Schmitz AJ, Hansen L, Haile A, Klebert MK, Pusic I, O'Halloran JA, Presti RM, Ellebedy $\mathrm{AH}$. SARS-CoV-2 infection induces long-lived bone marrow plasma cells in humans. Nature. 2021 May 24. doi: 10.1038/s41586-02103647-4. Epub ahead of print. PMID: 34030176.

2. Sekine T, Perez-Potti A, Rivera-Ballesteros O, Strålin K, Gorin JB, Olsson

$A$, et al. Robust $T$ Cell Immunity in Convalescent Individuals with

Asymptomatic or Mild COVID-19. Cell. 2020 Oct 1;183(1):158-168.e14. doi: 10.1016/j.cell.2020.08.017. Epub 2020 Aug 14. PMID: 32979941; PMCID: PMC7427556.

3. Michael P Busch, Mars Stone, Serosurveillance for Severe Acute Respiratory Syndrome Coronavirus 2 (SARS-CoV-2) Incidence Using Global Blood Donor Populations, Clinical Infectious Diseases, Volume 72, Issue 2, 15 January 2021, Pages 254-

256, https://doi.org/10.1093/cid/ciaa1116

4. Wouters $E$, Steenhuis $M$, Schrezenmeier $H$, Tiberghien $P$, Harvala $H$, Feys $\mathrm{HB}$, van der Schoot E. Evaluation of SARS-CoV-2 antibody titers and potency for convalescent plasma donation: a brief commentary. Vox Sang. 2021 May;116(5):493-496. doi: 10.1111/vox.13060. Epub 2020 Dec 23. PMID: 33368373.

5. Fenwick C, Croxatto A, Coste AT, Pojer F, André C, Pellaton C, Farina A, Campos J, Hacker D, Lau K, Bosch BJ, Gonseth Nussle S, Bochud M,

D'Acremont V, Trono D, Greub G, Pantaleo G. Changes in SARS-CoV-2 Spike versus Nucleoprotein Antibody Responses Impact the Estimates of Infections in Population-Based Seroprevalence Studies. J Virol. 2021 Jan 13;95(3):e01828-20. doi: 10.1128/JVI.01828-20. PMID: 33144321.

6. Nguyen-Contant $\mathrm{P}$, Embong AK, Kanagaiah $\mathrm{P}$, Chaves FA, Yang $\mathrm{H}$, Branche AR, Topham DJ, Sangster MY. S Protein-Reactive IgG and Memory B Cell Production after Human SARS-CoV-2 Infection Includes 
medRxiv preprint doi: https://doi.org/10.1101/2021.06.24.21259079; this version posted June 25, 2021. The copyright holder for this preprint (which was not certified by peer review) is the author/funder, who has granted medRxiv a license to display the preprint in perpetuity.

It is made available under a CC-BY-NC 4.0 International license.

Broad Reactivity to the S2 Subunit. mBio. 2020 Sep 25;11(5):e01991-20. doi: 10.1128/mBio.01991-20. PMID: 32978311; PMCID: PMC7520599.

7. Angulo FJ, Finelli L, Swerdlow DL. Estimation of US SARS-CoV-2 Infections, Symptomatic Infections, Hospitalizations, and Deaths Using Seroprevalence Surveys. JAMA Netw Open. 2021 Jan 4;4(1):e2033706. doi: 10.1001/jamanetworkopen.2020.33706. PMID: 33399860; PMCID: PMC7786245.

8. Cañete PF, Vinuesa CG. COVID-19 Makes B Cells Forget, but T Cells Remember. Cell. 2020 Oct 1;183(1):13-15. doi:

10.1016/j.cell.2020.09.013. Epub 2020 Sep 4. PMID: 32976799; PMCID: PMC7472965

9. Netea MG, van der Meer JW, van Crevel R. BCG vaccination in health care providers and the protection against COVID-19. J Clin Invest. 2021 Jan 19;131(2):e145545. doi: 10.1172/JCl145545. PMID: 33306484; PMCID: PMC7810495.

10. Gallais F, Velay A, Nazon C, Wendling M, Partisani M, Sibilia J, et al. Intrafamilial Exposure to SARS-CoV-2 Associated with Cellular Immune Response without Seroconversion, France. Emerg Infect Dis. 2021;27(1):113-121. https://dx.doi.org/10.3201/eid2701.203611

11. Martín MC, González Ml, Holgado N, Jimenez Al, Ortega N, Page I, Parrado A, Pérez $M$, Blanco-Peris $L$ Sustained seroprevalence of anti SARS-CoV-2 total immunoglobulins in asymptomatic blood donors medRxiv 2021.04.28.21256242;

doi: https://doi.org/10.1101/2021.04.28.21256242

12. Camara C, Lozano-Ojalvo D, Lopez-Granados E, Paz-Artal E, Pion M, Correa-Rocha R, et al. Differential effects of the second SARS-CoV-2 mRNA vaccine dose on T cell immunity in naïve and COVID-19 recovered individuals bioRxiv 2021.03.22.436441; doi: https://doi.org/10.1101/2021.03.22.436441 
medRxiv preprint doi: https://doi.org/10.1101/2021.06.24.21259079; this version posted June 25, 2021. The copyright holder for this preprint (which was not certified by peer review) is the author/funder, who has granted medRxiv a license to display the preprint in perpetuity.

It is made available under a CC-BY-NC 4.0 International license.

13. Kohmer N, Westhaus S, Rühl C, Ciesek S, Rabenau HF. Brief clinical evaluation of six high-throughput SARS-CoV-2 IgG antibody assays. $J$ Clin Virol. 2020;129:104480. doi:10.1016/j.jcv.2020.104480

14. Varona JF, Madurga R, Peñalver F, Abarca E, Almirall C, Cruz M, Ramos E, Castellano-Vazquez JM. kinetics of anti-SARS-CoV-2 antibodies over time. Results of 10 month follow up in over 300 seropositive Health Care Workers. Eur J Intern Med. 2021 May 25:S0953-6205(21)00187-4. doi: 10.1016/j.ejim.2021.05.028. Epub ahead of print. PMID: 34090748; PMCID: PMC8148432.

15. Isho B, Abe KT, Zuo M, et al. Persistence of serum and saliva antibody responses to SARS-CoV-2 spike antigens in COVID-19 patients. Sci Immunol. 2020;5(52):eabe5511. doi:10.1126/sciimmunol.abe5511

16. Jurado A, Martín MC, Abad-Molina C, et al. COVID-19: age, Interleukin-6, Creactive protein, and lymphocytes as key clues from a multicentre retrospective study. Immun Ageing. 2020;17:22

17. Martín MC, Jurado A, Abad-Molina C, Orduña A, Yarce O, Navas AM, et al. The age again in the eye of the COVID-19 storm: evidence-based decision making. Immun Ageing. 2021 May 20;18(1):24. doi: 10.1186/s12979-021-00237-w. PMID: 34016150; PMCID: PMC8134808.

18. Imran MM, Ahmad U, Usman U, Ali M, Shaukat A, Gul N. Neutrophil/lymphocyte ratio-A marker of COVID-19 pneumonia severity. Int J Clin Pract. 2021 Apr;75(4):e13698. doi: 10.1111/ijcp.13698. Epub 2021 Jan 12. PMID: 32892477.

19. Marongiu F, Grandone E, Scano A, Orrù G, Marongiu S, Gerosa C, Fanni D, Faa G, Barcellona D. Infectious agents including COVID-19 and the involvement of blood coagulation and fibrinolysis. A narrative review. Eur Rev Med Pharmacol Sci. 2021 May;25(10):3886-3897. doi: 10.26355/eurrev_202105_25956. PMID: 34109597.

20. Chao Y, Rebetz J, Bläckberg A, Hovold G, Sunnerhagen T, Rasmussen M, Semple JW, Shannon O. Distinct phenotypes of platelet, monocyte, and neutrophil activation occur during the acute and convalescent phase of COVID-19. Platelets. 2021 May 17:1-11. doi: 10.1080/09537104.2021.1921721. Epub ahead of print. PMID: 33999778; PMCID: PMC8146300. 
medRxiv preprint doi: https://doi.org/10.1101/2021.06.24.21259079; this version posted June 25, 2021. The copyright holder for this preprint (which was not certified by peer review) is the author/funder, who has granted medRxiv a license to display the preprint in perpetuity.

It is made available under a CC-BY-NC 4.0 International license.

21. Fenwick C, Croxatto A, Coste AT, et al. Changes in SARS-CoV-2 Spike versus Nucleoprotein Antibody Responses Impact the Estimates of Infections in Population-Based Seroprevalence Studies. J Virol. 2021;95(3):e01828-20. Published 2021 Jan 13. doi:10.1128/JVI.01828-20

22. Long QX, Tang XJ, Shi QL, et al. Clinical and immunological assessment of asymptomatic SARS-CoV-2 infections. Nat Med. 2020;26(8):12001204. doi:10.1038/s41591-020-0965-6

23. Dos Santos JMB, Soares CP, Monteiro FR, et al. In Nasal Mucosal Secretions, Distinct IFN and IgA Responses Are Found in Severe and Mild SARS-CoV-2 Infection. Front Immunol. 2021;12:595343. Published 2021 Feb 25. doi:10.3389/fimmu.2021.595343

24. Noval MG, Kaczmarek ME, Koide A, et al. Antibody isotype diversity against SARS-CoV-2 is associated with differential serum neutralization capacities. Sci Rep. 2021;11(1):5538. Published 2021 Mar 10. doi:10.1038/s41598-021-84913-3 
medRxiv preprint doi: https://doi.org/10.1101/2021.06.24.21259079; this version posted June 25, 2021. The copyright holder for this preprint (which was not certified by peer review) is the author/funder, who has granted medRxiv a license to display the preprint in perpetuity.

\begin{tabular}{|c|c|c|c|c|c|c|c|c|c|c|}
\hline & \multicolumn{4}{|c|}{ Wane } & \multicolumn{4}{|c|}{ Keep } \\
\hline & & & $\mathrm{n}$ & mean & SD & IQR & $\mathrm{n}$ & mean & SD & IQR \\
\hline \multirow[t]{4}{*}{$\lg A$} & under 30 & & 1 & 352.0 & 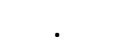 & $352-352$ & 22 & 234.9 & 74.2 & $174-282$ \\
\hline & $\geq 30$ and $<45$ & & 1 & 486.0 & . & $486-486$ & 62 & 255.6 & 92.9 & $179-311$ \\
\hline & $\geq 45$ and $<60$ & & 3 & 261.3 & 158.7 & $150-443$ & 75 & 206.6 & 75.3 & $155-252$ \\
\hline & $\geq 60$ and $<75$ & & 0 & • & & & 8 & 228.5 & 70.4 & $185-287.5$ \\
\hline \multirow[t]{4}{*}{$\lg G$} & under 30 & & 1 & 1003.0 & . & $1003-1003$ & 22 & 1052.8 & 196.5 & $953-1144$ \\
\hline & $\geq 30$ and $<45$ & & 1 & 1155.0 & . & $1155-1155$ & 62 & 1075.2 & 143.1 & $989-1145$ \\
\hline & $\geq 45$ and $<60$ & & 3 & 953.0 & 120.7 & $875-1092$ & 75 & 1040.9 & 176.3 & $905-1162$ \\
\hline & $\geq 60$ and $<75$ & & 0 & . & . & & 8 & 1012.0 & 116.3 & 937.5-1079 \\
\hline \multirow[t]{4}{*}{$\operatorname{lgM}$} & under 30 & & 1 & 138.0 & . & $138-138$ & 22 & 129.6 & 53.0 & 84-175 \\
\hline & $\geq 30$ and $<45$ & & 1 & 85.0 & $\cdot$ & $85-85$ & 62 & 129.3 & 66.4 & $89-182$ \\
\hline & $\geq 45$ and $<60$ & & 3 & 94.3 & 50.8 & $47-148$ & 75 & 108.7 & 53.0 & 70-141 \\
\hline & $\geq 60$ and $<75$ & & 0 & . & . & & 8 & 142.6 & 115.9 & $71.5-147.5$ \\
\hline \multirow[t]{4}{*}{ WBC } & under 30 & & 1 & 4.9 & . & $4.9-4.9$ & 43 & 6.6 & 1.9 & 5.4-7.7 \\
\hline & $\geq 30$ and $<45$ & & 1 & 7.1 & . & 7.1-7.1 & 118 & 7.5 & 1.8 & $6.2-8.5$ \\
\hline & $\geq 45$ and $<60^{*}$ & $p=0.047$ & 3 & 9.5 & 2.5 & $6.8-11.9$ & 154 & 6.7 & 1.6 & $5.6-7.6$ \\
\hline & $\geq 60$ and $<75$ & & 0 & . & . & & 14 & 6.3 & 1.3 & $5.2-7$ \\
\hline \multirow[t]{4}{*}{$\mathrm{Hb}$} & under 30 & & 0 & . & . & & 40 & 1.0 & 0.0 & $1-1$ \\
\hline & $\geq 30$ and $<45$ & & 4 & 15.3 & 1.5 & $14-16.5$ & 156 & 15.1 & 1.1 & $14.3-15.8$ \\
\hline & $\geq 45$ and $<60$ & & 0 & $\cdot$ & $\cdot$ & & 14 & 15.1 & 1.0 & $14.8-15.5$ \\
\hline & $\geq 60$ and $<75$ & & 1 & 15.4 & . & $15.4-15.4$ & 43 & 15.2 & 1.1 & $14.4-15.9$ \\
\hline \multirow[t]{4}{*}{$\mathrm{Hb}$} & under 30 & & 1 & 46.9 & . & 46.9-46.9 & 43 & 45.3 & 2.9 & 43.1-47.4 \\
\hline & $\geq 30$ and $<45$ & & 1 & 43.3 & . & $43.3-43.3$ & 118 & 45.2 & 2.8 & $43.3-47.2$ \\
\hline & $\geq 45$ and $<60$ & & 4 & 46.6 & 4.5 & $43.3-50$ & 156 & 45.1 & 3.2 & $42.8-47.4$ \\
\hline & $\geq 60$ and $<75$ & & 0 & • & . & & 14 & 44.7 & 3.0 & $43.7-45.9$ \\
\hline \multirow[t]{4}{*}{ Platelets } & under 30 & & 1 & 226.0 & . & $226-226$ & 43 & 253.4 & 51.8 & 214-295 \\
\hline & $\geq 30$ and $<45$ & & 1 & 224.0 & . & $224-224$ & 118 & 254.7 & 53.3 & $\begin{array}{c}215-281 \\
206.5-\end{array}$ \\
\hline & $\geq 45$ and $<60^{*}$ & $p=0.019$ & 4 & 307.0 & 48.4 & $280-334$ & 156 & 240.3 & 50.0 & 260.5 \\
\hline & $\geq 60$ and $<75$ & & 0 & • & . & & 14 & 240.7 & 36.4 & $221-263$ \\
\hline \multicolumn{11}{|l|}{ Neutrophil } \\
\hline \multirow[t]{4}{*}{ count } & under 30 & & 1 & 2.8 & . & $2.8-2.8$ & 43 & 4.0 & 1.5 & $2.9-4.8$ \\
\hline & $\geq 30$ and $<45$ & & 1 & 4.7 & . & $4.7-4.7$ & 118 & 4.6 & 1.7 & $3.5-5.3$ \\
\hline & $\geq 45$ and $<60^{*}$ & $p=0.019$ & 4 & 5.9 & 1.8 & $4.5-7.4$ & 156 & 4.0 & 1.2 & $3.1-4.6$ \\
\hline & $\geq 60$ and $<75$ & & 0 & $\cdot$ & . & & 14 & 3.7 & 1.0 & $2.8-4.5$ \\
\hline \multicolumn{11}{|l|}{ Neutrophil } \\
\hline \multirow[t]{4}{*}{$\%$} & under 30 & & 1 & 55.8 & . & $55.8-55.8$ & 43 & 59.0 & 8.3 & $53.3-63.6$ \\
\hline & $\geq 30$ and $<45$ & & 1 & 66.7 & & $66.7-66.7$ & 118 & 59.8 & 8.1 & $54-63.9$ \\
\hline & $\geq 45$ and $<60^{*}$ & $p=0.014$ & 4 & 67.0 & 2.5 & 64.9-69.1 & 156 & 58.7 & 7.4 & $54.2-63.8$ \\
\hline & $\geq 60$ and $<75$ & & 0 & • & . & & 14 & 58.1 & 7.4 & $54.1-65.2$ \\
\hline \multicolumn{11}{|c|}{ Lymphocyte } \\
\hline \multirow[t]{4}{*}{ count } & under 30 & & 1 & 1.8 & . & $1.8-1.8$ & 43 & 2.1 & 0.6 & $1.7-2.5$ \\
\hline & $\geq 30$ and $<45$ & & 1 & 1.9 & . & $1.9-1.9$ & 118 & 2.3 & 0.5 & $1.9-2.6$ \\
\hline & $\geq 45$ and $<60^{*}$ & $p=0.005$ & 4 & 1.9 & 0.6 & $1.5-2.4$ & 156 & 2.1 & 0.6 & $1.7-2.4$ \\
\hline & $\geq 60$ and $<75$ & & 0 & $\cdot$ & . & & 14 & 2.0 & 0.5 & $1.6-2.4$ \\
\hline
\end{tabular}


medRxiv preprint doi: https://doi.org/10.1101/2021.06.24.21259079; this version posted June 25, 2021. The copyright holder for this preprint (which was not certified by peer review) is the author/funder, who has granted medRxiv a license to display the preprint in perpetuity.

It is made available under a CC-BY-NC 4.0 International license.

Lymphocyte

$\% \quad$ under 30
$\geq 30$ and $<45$
$\geq 45$ and $<60$
$\geq 60$ and $<75$

Monocyte

count

under 30

$\geq 30$ and $<45$

$\geq 45$ and $<60 *$

$\geq 60$ and $<75$

Monocyte

$\%$

under 30

$\geq 30$ and $<45$

$\geq 45$ and $<60$

$\geq 60$ and $<75$

Eosinophil

count

under 30

$\geq 30$ and $<45^{*}$

$\geq 45$ and $<60^{*}$

$\geq 60$ and $<75$

Eosinophil

$\%$

Bosophil

count

under 30

$\geq 30$ and $<45$

$\geq 45$ and $<60$

$\geq 60$ and $<75$

$\begin{array}{ll}p=0.049 & 1 \\ p=0.034 & 4 \\ & 0\end{array}$

1

1.8

0.1

0.0

0.3

0.2

$0.1-0.1$

0.3-0.3

0.4-0.4

$0.5-0.7$

5.3

5.8

6.7

0.6

5.3-5.3

5.8-5.8

43
118

6.3-7

156

14

43
118
156
14

0.4

0.1

$\begin{array}{ll}0.4 & 0.1\end{array}$

$\mathbf{0 . 4} 0.1$

$\mathbf{0 . 4} 0.1$

$6.2 \quad 1.4$

$6.1 \quad 1.4$

$6.3 \quad 1.3$

$6.5 \quad 0.7$

0-0 118

43

0.1

0.1

$0.2-0.4$

156

0.2

0.1

0.2

0.1

$0.2 \quad 0.1$

$\begin{array}{llll}1.8-1.8 & 43 & \mathbf{2 . 1} & 1.5\end{array}$

$\begin{array}{llll}0.3-0.3 & 118 & \mathbf{2 . 2} & 1.6\end{array}$

3.8

2.9

2.1-5.4

156

$2.7 \quad 1.8$

14

2.7

0-0 43

0-0 118

0-0

118

$\mathbf{0 . 0} \quad 0.0$

156

$\mathbf{0 . 0} \quad 0.0$

0.0

0.0

$\geq 60$ and $<75$

Basophil \% under 30

$\geq 30$ and $<45$

$\geq 45$ and $<60$

$\geq 60$ and $<75$

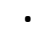

0.5

0.4

0.5
14

$\mathbf{0 . 0} \quad 0.0$

0.5-0.5 43

$\mathbf{0 . 0} \quad 0.0$

$0.5 \quad 0.2$

0.4-0.4 118

$0.5 \quad 0.3$

0.4-0.6

156

$0.6 \quad 0.3$

$\begin{array}{lll}14 & 0.6 & 0.3\end{array}$

$0-0.1$

0-0.1

$0.3-0.6$

$0.3-0.6$

0.4-0.7

Supplementary Table 1. Laboratory data stratified by age in donations keeping or

384 waning antibodies Wane: present donation positive, next one, negative; keep:

385 both positive 